\title{
Support and Opposition to Abortion in Finland
}

\author{
HEIKKI ERVASTI, Ph.D. \\ Assistant Professor (acting) \\ University of Turku \\ Department of Social Policy
}

\section{Introduction}

During the last couple of decades, the yearly number of abortions has decreased notably in Finland. Since the beginning of the 1970s, abortion rates have decreased among all age groups of women (Notkola 1995, 29-30). In 1995, less than 8 abortions were performed per 1,000 women aged 15-49 in Finland, which is less than in most other countries with reliable registers (Rasimus 1993). According to most authors (e.g. Kosunen 1993; 1996; Nurmi 1993; Rimpelä 1993) development of health services, more effective contraceptive methods and increasing knowledge about them, as well as public subvention of contraceptives, have all contributed to this development.

Public perceptions of abortion have varied in different times and countries (see Luker 1984). As Scott (1998) notes, during the period of criminalized abortion in the Western countries, the reality of illegal abortion as secret, and often dirty, and dangerous, helped shape the perception of abortion as deviant and wrong. During the 1960s, when abortion was introduced to the public agenda for reform in several Western countries, traditional views were called into question. Finally, when several countries liberalized their legislation in the early 1970s, it was noted that the legal changes were grounded in a dramatic increase in public approval of abortion (Granberg and Granberg 1980; Jaffe et al. 1981). But although it has been reported (Scott 1998; Evers and McGee 1980) that, in general, abortion attitudes have become ever more liberal, in most countries, there is also a visible, although not numerically populous proportion of people strongly opposing abortion. The opponents of abortion, it has been reported, hold more intense attitudes and they are more willing to be politically mobilized than those holding more permissive attitudes (Cook et al. 1993; Cochran and Beeghley 1991; Luker 1984, 223; Tamney et al. 1992; Scott and Schuman 1988). As Deflem $(1998,795)$ puts it, "cultural dualism" has remained a constant factor in the abortion debate.

In this paper, I will provide an insight into the Finnish abortion culture. In particular, I will analyze the public perceptions of abortion with a recent cross-sectional survey data set. The 
task of my analysis is twofold. First, I will examine the general levels of acceptance and opposition to abortion. How widespread are support and opposition to abortion? Second, I will focus on how large are the attitudinal cleavages existing between various segments of the Finnish population and what background variables correlate with opposition and permissiveness of abortion. Are there signs of cultural dualism? Who are the people who oppose abortion and who are the ones holding more liberal attitudes? Kristin Luker (1984, 158) suggests that attitudes toward abortion are merely "the tip of the iceberg." Entire world views are called into play when the issue is abortion. Thus, in addition to structural and demographic variables, I will pay special attention to the effects of ideological determinants like religion, feminism and political orientation on abortion attitudes.

The structure of this article is as follows: First, I will review earlier discussion and research on the possible background of attitudes toward abortion. After that I will present the data and methods used in the analysis and conduct the empirical analysis. Finally I will discuss the wider connections and relevance of the obtained results.

\section{The possible background of attitudes toward abortion}

Earlier research has identified three especially important ideological factors affecting attitudes toward abortion. These are religiosity, perceptions of gender roles in society and political orientation. Furthermore, it can also be hypothesized that certain attitudinal cleavages exist between men and women, people with diverging positions in stratification hierarchies and between different age groups. In this section I will discuss the hypothetical effects of these factors and the possible causal relations between them. Note that the hypothetical causal chains discussed in the following do not claim that everyone's perceptions of abortion are strictly grounded in his/her ideological and structural background. Instead, the hypotheses suggest common causal chains of reasoning.

Religion. Religious beliefs are often considered the most important factor in the formation of attitudes toward abortion (Driedger and Halli 1997; Himmelstein 1986; Kelley et al. 1993; Luker 1984). Religiosity can be hypothesized to generate opposition to abortion in two ways.

First, a view that God created the world and human beings including their reproductive system is a fundamental characteristic of traditional Christianity. In this view, interfering with reproduction disrupts the natural and good order of things. As abortion violates the idea of the sacredness of human life, it is a rebellion against God's design. In this view, the embryo is a distinct living person from the moment of conception, consequently with rights and interests of its own, certainly including the right to live. Abortion is therefore the murder of an innocent being. (Tamney et al. 1992; Kelley et al. 1993.)

Second, Christian tradition is relevant to abortion because it emphasizes the sinfulness of human nature. In Christian tradition desires for physical pleasures or comforts are viewed as corrupting, and the need to control the human's baser nature is emphasized. Using sex purely for pleasure is considered animalistic. This puritanical perspective finds expression in a com- 
mitment to various traditional moral rules, but in the field of reproduction and sexual behavior this perspective is the most apparent. As well reported, religiosity correlates clearly with sexual attitudes and behavior (Jensen et al. 1990; Cochran and Beeghley 1991). So, as religious beliefs enforce disapproval of sexual permissiveness and abstaining attitudes on sexuality, it may also lead to opposition to abortion. People who oppose sexual permissiveness are likely to view unwanted pregnancies as a deterrent and as a just punishment for illicit sexual activity, and hence are likely to view abortion as wrong because it allows women to escape the consequences of their wrongdoing. Furthermore, it might also facilitate male sexual irresponsibility (Kelley et al. 1993).

Gender role attitudes. Contrary to religiosity, liberal gender role attitudes can be hypothesized to enforce permissive attitudes toward abortion. The abortion issue is clearly a feminist issue by virtue of the specificity of procreation to women and the impact of pregnancy and birth upon women's life options. Indeed, abortion rights have been an important issue for feminist movements in several countries (see Costain and Costain 1987; Ferree 1987; Beckwith 1987; see also Ramirez and McEneaney 1997). According to Luker (1984), the abortion controversy has always been less concerned with the welfare of the fetus than with the social status of women and mothers. Although on the surface it is the embryo's fate which seems to be at stake, the abortion debate is actually about the meaning of women's lives. In essence, the hard-fought abortion debate is a "referendum on the place and meaning of motherhood" (Luker 1984, 193). Kelley and his colleagues (1993) argue that attitudes toward women's employment, in particular, are among the most important predictors of abortion attitudes. In traditional gender role thinking women's legitimate roles are limited to mother, nurturer and homemaker. In this view, abortion allows women to escape from their proper traditional roles into illegitimate roles in working life and thus threatens the special status of motherhood as women's highest vocation. On these grounds it can be expected that traditional gender role thinking and especially negative attitudes toward women's employment form one of the major sources for opposition to abortion.

Stratification hierarchies. Recently, the effects of class variables like educational attainment, occupational status and income on attitudes toward all social issues have been a subject of a considerable debate. Two conflicting views have been manifested. Traditionally all sorts of social conservatism has been connected to the upper strata. Some authors (see Himmelstein and McRae 1988, 498 for an overview) have argued that as the result of the ongoing postindustrial structural change, an inverse relationship between socioeconomic status and social issues has emerged. Most prominently, Inglehart (1990) argues that the materialistically well-off upper strata and especially the well-educated have adopted socially liberal (although perhaps economically conservative) attitudes. Himmelstein and McRae (1988) emphasize that several dimensions of status and class each have independent effects on social attitudes. Furthermore, they show that the relationship between social liberalism and socioeconomic status varies from issue to issue. However, they find that a higher socioeconomic status does indeed have a liberalizing effect on abortion attitudes.

Political orientation. Closely connected to the theories of the postindustrial structural change, it has been suggested that the political settings of the Western countries are rapidly changing. As a result, the traditional class-based left-right divide among the general publics 
of these countries has vanished (see Inglehart 1990, 273-274). However, there is also empirical evidence suggesting that people's attitudes toward not only economic and political but also on social and moral issues still strongly correlate with their political preferences (see Ervasti 1997). Inglehart argues that as the traditional class conflicts lose their importance as political issues within the structural change, "the strongest indicators of whether one is on the left or right are the New Politics issues, such as support for liberalizing abortion" $(1990,275)$. On these grounds it is well-reasoned to test the effects of political orientation also on abortion attitudes.

Historically, conservatives have been distrustful of man's basic nature and have emphasized the need for restraining institutions, as Lenski (1971, cited in Tamney et al. 1992) puts it. Thus, political conservatism may provide an important ideological basis for limiting arguments about abortion. This argument has also received empirical support. For example, Wilcox (1989) showed that there is a clear correlation between political conservatism and anti-abortion stances. Similarly, Inglehart $(1990,295)$ found that abortion attitudes related to a respondent's self-placement on a left-right scale.

Gender. Perhaps surprisingly, earlier research has found only minor differences between men and women's stances toward abortion (e.g. Scott 1998; Tamney et al. 1992). In fact, there is even evidence that men hold slightly more liberal attitudes toward abortion than women (e.g. Erkkola and Kontula 1993; Kelley et al. 1993). The reason for this may lie in intervening variables. Most importantly, women are usually more religious than men and therefore may find it difficult to accept abortion (Kelley et al. 1993, 604).

Age. Many have argued that age (or cohort) correlates with conservative social attitudes. According to Inglehart (1990), the younger generations have adopted more liberal world views than their predecessors. In a cross-sectional survey like this, it is unfortunately impossible to assess whether attitudes change with age or whether the difference is generational and continues to exist regardless of age. However, earlier evidence suggests that younger people hold more liberal attitudes toward abortion than older people (Kelley et al. 1993; Inglehart 1990). Furthermore, the well-reported facts that older people are more religious and more antifeminist than younger people also contribute indirectly to age differences in abortion attitudes (see Ervasti 1998a for an overview).

\section{Data and methods}

Data for this study were gathered in a mail survey conducted in Finland during the autumn of 1995 with a representative sample of the Finnish population aged 18 to 75 (see Söderling 1997). The response rate was 52 percent, and the effective size of the sample was 753 . Although the response rate was rather low, extensive comparisons with Finnish census data show that the sample closely approximates the Finnish population in terms of most important variables (further details are given in Söderling 1997, 8 or are available from the author on request). 
The exact wordings and measurement of the variables used in the analysis are shown in Table 1 (page 143). Attitudes toward abortion were measured with three variables. These items refer to the justifiability of abortion in different situations. The measurement of religiosity was based on two observed variables. These items measure religious beliefs rather than religious behavior (like church attendance). This way, more reliable and less skewed measures are attained. Most Finns attend church services only on special occasions like weddings, funerals, etc. Only a small minority attend church services regularly. Nevertheless, a notable proportion of Finns still support the essential principles of Christianity such as the existence of a personal God and the hope of heaven. (Heino 1997, 17-21.) Gender role attitudes or, more precisely, attitudes on women's employment were also measured with two observed variables. Educational attainment is measured in equivalent full-time years of study. Political orientation is measured with a scale ranging from 0 (=left) to 100 (=right). This scale, shown to be reliable in previous research (Ervasti 1997; 1998b), is based on an item asking which party the respondents voted for in the previous parliamentary election. Age is measured in years and income in thousands of Finnmarks per month. Occupational status is based on the International Standard Coding of Occupations (ISCO), distinguishing between unskilled manual workers, skilled manual workers, routine non-manual workers, white collar employees and self-employed (entrepreneurs and farmers). In addition, there is also the occupational group 'other,' consisting mostly of students, housewives and other small groups not active in the labor force whose occupation is unknown.

Figure 1. Description of the model used in the analysis

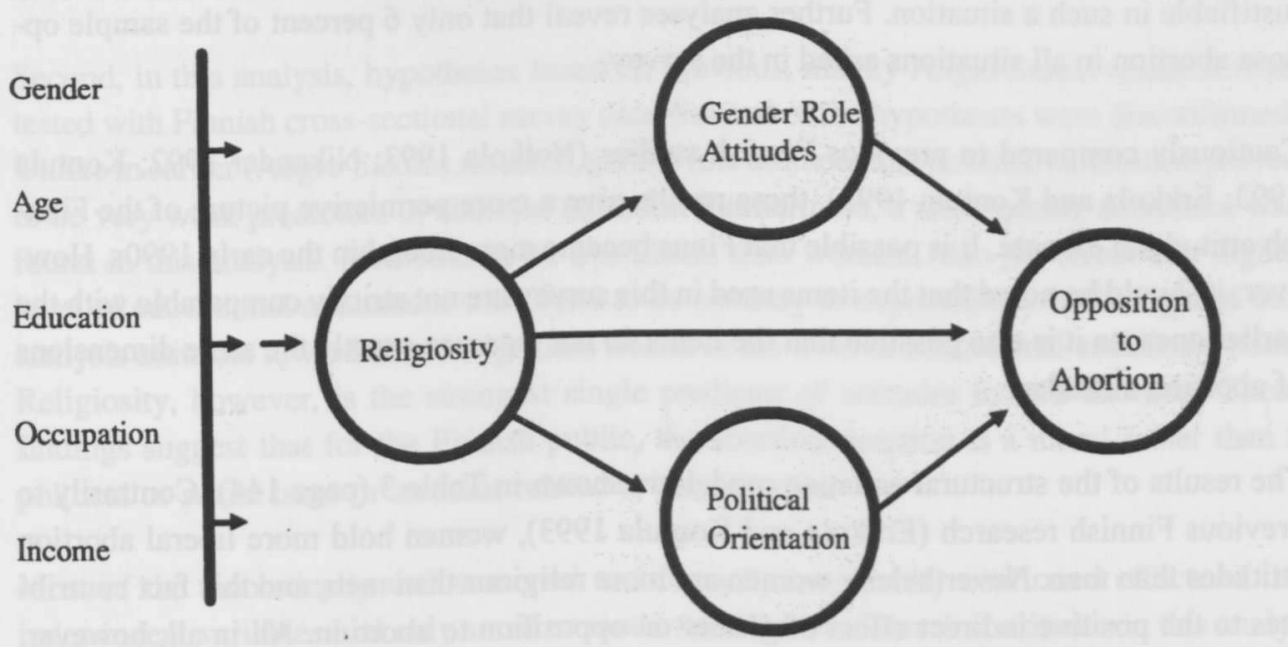

As the method of analysis, I have employed a linear structural equation model with latent variables (e.g. Bollen 1989) to test a theoretical model based on the above hypothesized effects of religiosity, gender role attitudes and political orientation as well as stratification 
hierarchies, gender and age on opposition to abortion. The theoretical model is shown in Figure 1. In the model, the exogenous variables of stratification hierarchies, age and gender directly affect all the endogenous variables. Furthermore, there are also causal relationships between the endogenous variables. Religiosity is seen as a long-term variable and thus it is located on the first causal level among the endogenous variables. Religion is generally learned from one's parents starting at a very early age. Gender role attitudes as well as political orientation, in contrast, may be viewed as more recent phenomena, or at least ones that come later in the life course and thus depend on previous religiosity, among other things.

As the main purpose of my analysis is to determine the relative importance of each variable, I estimated standardized parameters. Since most of the variables are ordinal, the analysis is based on polychoric and polyserial correlations (see Jöreskog and Sörbom 1996, 8-10; 1489). The factor loadings (Table 1) suggest clear and strong factors. The model fits the data well: Chi-square with 50 degrees of freedom is 91.50 , the Goodness of Fit Index (GFI) is reasonably high (.98) and the Root Mean Square Error of Approximation (RMSEA) is satisfactorily low (.033). No ad hoc error correlations were allowed in the model. First, I estimated the full structural model and then pruned out (i.e. fixed to zero) the effects that were not significant at the 5 percent level.

\section{Results}

As Table 2 (page 144) shows, most Finns hold quite liberal attitudes toward abortion. Almost 60 percent of the respondents accept abortion on demand and in the case of poverty or other social problems in the family. The number of those accepting abortion in the case the child would be disabled is even higher. No less than 75 percent of the sample think that abortion is justifiable in such a situation. Further analyses reveal that only 6 percent of the sample oppose abortion in all situations asked in the survey.

Cautiously compared to previous Finnish studies (Notkola 1993; Nikander 1992; Kontula 1993; Erkkola and Kontula 1993), these results give a more permissive picture of the Finnish attitudinal climate. It is possible that Finns became more liberal in the early 1990s. However, it should be noted that the items used in this survey are not strictly comparable with the earlier ones, so it is also possible that the items do not measure exactly the same dimensions of abortion attitudes.

The results of the structural equation model are shown in Table 3 (page 144). Contrarily to previous Finnish research (Erkkola and Kontula 1993), women hold more liberal abortion attitudes than men. Nevertheless, women are more religious than men, and this fact contributes to the positive indirect effect of gender on opposition to abortion. All in all, however, women do not oppose abortion as often as men (the total effect of being a woman on opposition to abortion is -.10 ).

Age correlates positively with religiosity and especially with support for traditional gender roles, and negatively with rightist political orientation, but the effect of age on abortion atti- 
tudes is very small. Also both the direct and indirect effects of occupational status are nonsignificant.

Education and income have opposite effects on abortion attitudes. Contrary to expectation, education stimulates non-permissive attitudes toward abortion. Again, this finding is not consistent with previous Finnish findings (e.g. Kontula 1993, 28; Notkola 1993, 91). However, it should be noted that unlike this analysis, previous Finnish research has reported only bivariate results (Kontula 1993) or it has been based on a sample representing only women (Notkola 1993). As hypothesized above, different dimensions of stratification hierarchies have independent effects on abortion attitudes: A higher level of income is associated with a lower level of religiosity and thus, the indirect effect of income on opposition to abortion is negative.

As expected, religiosity is the best predictor of opposition to abortion. However, political orientation and, surprisingly, gender role attitudes do not correlate with abortion attitudes. This finding suggests that Finns consider the abortion issue a moral rather than a political issue or a question related to gender inequality.

\section{Conclusions}

The first aim of this analysis was to estimate the support for and especially the opposition to abortion in Finland. The results show that Finns hold quite liberal stances on the abortion issue. Clearly a majority of Finns support free abortion. Although not strictly comparable to previous Finnish research, the results of this analysis give a slightly more liberal picture of abortion attitudes of the Finnish public than earlier research.

Second, in this analysis, hypotheses based on previous, mainly Anglo-Saxon research were tested with Finnish cross-sectional survey data. Several of the hypotheses were disconfirmed. Unlike in earlier (Anglo-Saxon) research, gender role attitudes and political orientation proved to be very weak predictors of abortion attitudes. Furthermore, a clear gender difference was found in this analysis. Men tend to be less liberal than women. Also the effect of a higher level of educational attainment was found to be contrary to expectations. In the light of this analysis attitudes toward abortion get less liberal as the level of educational attainment rises. Religiosity, however, is the strongest single predictor of attitudes toward abortion. These findings suggest that for the Finnish public, the abortion question is a moral rather than a political or social issue or an issue related to gender roles.

Most of the theoretically well-reasoned and formerly empirically confirmed effects of the independent variables had only small or moderate effects on abortion attitudes in this analysis. Also the percentage of variance in abortion attitudes explained with these independent variables was comparatively low. This suggests that the Finnish public holds consensual attitudes toward abortion. Compared to the results of recent studies in several countries, this analysis suggests that in Finland, the abortion controversy is not only less politicized but also it reflects a lesser grade of cultural dualism. 


\section{References}

Beckwith, K. 1987. Response to feminism in the Italian parliament: Divorce, abortion, and sexual violence legislation. In: The women's movements of the United States and Western Europe, edited by M.F. Katzenstein and C. McClurg Mueller, pp. 153-171. Philadelphia: Temple University Press.

Bollen, K. 1989. Structural equations with latent variables. New York: Wiley.

Cochran, John K. and L. Beeghley. 1991. The influence of religion on attitudes toward nonmarital sexuality: A preliminary assessment of reference group theory. Journal for the Scientific Study of Religion 30 (1):45-62.

Cook, Elizabeth A., T.G. Jelen and C. Wilcox. 1993. Catholicism and abortion attitudes in the American states: A contextual analysis. Journal for the Scientific Study of Religion 32 (3):223-230.

Costain, A. and W.D. Costain. 1987. Strategy and tactics of the women's movement in the United States: The role of political parties. In: The women's movements of the United States and Western Europe, edited by M.F. Katzenstein and C. McClurg Mueller, pp. 196-214. Philadelphia: Temple University Press.

Deflem, M. 1998. The boundaries of abortion law: Systems theory from Parsons to Luhman and Habermas. Social Forces 76 (3):775-818.

Driedger, L. and S. Halli. 1997. Pro life or pro choice: Politics of career and homemaking. Population Studies 51 (2):129-137.

Erkkola, R. and O. Kontula 1993. Syntyvyyden sääntely (Fertility control). In: Suomalainen seksi, edited by O. Kontula and E. Haavio-Mannila, pp. 343-370. Porvoo, Helsinki, Juva: WSOY.

Ervasti, H. 1997. The rise of the new political agenda: The end of the "democratic class struggle"? Paper presented in 'Nordiske socialpolitiske forskerseminar'. Köge, Denmark, November 6-8 1997.

Ervasti, H. 1998a. Suomalaisten perhe- ja sukupuolirooliasenteet (Family and gender role attitudes in Finland). In: Sukupuolten tasa-arvosta ristiin rastiin, edited by O. Kangas and K. Nurmi. Forthcoming.

Ervasti, H. 1998b. Social classes, individualistic criticism and support for welfare services. Department of Social Policy. Series B:20/1998.

Evers, M. and J. McGee. 1980. The trend and pattern in attitudes toward abortion in the United States, 1965-1977. Social Indicators Research 7 (2), 251-267.

Ferree, M. M. 1987. Equality and autonomy: Feminist politics in the United States. In: The Women's Movements of the United States and Western Europe, edited by M. F. Katzenstein and C. McClurg Mueller, pp. 172-195. Philadelphia: Temple University Press.

Granberg, D. and B. Granberg. 1980. Abortion attitudes, 1965-1980: Trends and determinants. Family Planning Perspectives 12 (5):250-261.

Heino, H. 1997. Mihin Suomi tänään uskoo (What do Finns believe in today?). Porvoo-Helsinki-Juva: WSOY.

Himmelstein, J. 1986. The social basis of antifeminism: Religious networks and culture. Journal for the Scientific Study of Religion 25 (1):1-139.

Himmelstein, J. and J. McRae. 1988. Social issues and socioeconomic status. Public Opinion Quarterly 52 (4):492-512. 
Inglehart, R. 1990. Culture shift in advanced industrial society. Princeton: Princeton University Press.

Jaffe, F. S., B. L. Lindheim and P. R. Lee. 1981. Abortion Politics. New York: McGraw Hill.

Jensen, L., R. J. Newell and T. Holman. 1990. Sexual behavior, church attendance, and permissive beliefs among unmarried young men and women. Journal for the Scientific Study of Religion 29 (1):113-117.

Jöreskog, K. and D. Sörbom. 1996. PRELIS 2: User's reference guide. Chicago: Scientific Software.

Kelley, J., M.R.D. Evans and B. Headey. 1993. Moral reasoning and political conflict: The abortion controversy. British Journal of Sociology 44 (4):589-612.

Kontula, O. 1993. Ketkä hyväksyvät vapaan abortin? (Who accepts free abortion?). In: M. Rimpelä, O. Kontula \& I-L. Notkola: Suomalaisia mielipiteitä raskauden keskeytyksestä. Stakes, Aiheita 34/1993. Helsinki: Stakes, National Research and Development Centre for Welfare and Health.

Kosunen, E. 1993. Teini-ikäisten raskaudet ja ehkäisy (Teenagers' pregnancies and contraception. Raportteja, No. 99. Helsinki: Stakes, National Research and Development Centre for Welfare and Health.

Kosunen, E. 1996. Adolescent reproductive health in Finland: Oral contraception, pregnancies and abortions from the 1980 s to the 1990s. Acta Universitatis Tamperensis. Ser A. Vol. 486.

Luker, K. 1984. Abortion and the Politics of Motherhood. Berkeley: University of California Press.

Nikander, T. 1992. Naisen elämänkulku ja perheellistyminen (Womens' life courses and family formation). Helsinki: Statistics Finland.

Notkola, I-L. 1993. Suomalaisten suhtautuminen aborttiin (Finns' attitudes toward abortion). In: Raskauden keskeyttäminen - Suomalaisia valintoja 1990-luvulla, edited by M. Rimpelä and M. Ritamo, pp. 87-102. Raportteja, No. 126. Helsinki: Stakes, National Research and Development Centre for Welfare and Health.

Notkola, I-L. 1995. Cohort fertility changes and period fertility in 1960-1990 in Finland. Yearbook of Population Research in Finland 32:19-31.

Nurmi, T. 1993. Raskaudenkeskeytyksistä ihmissuhde- ja sukupuolikasvatukseen (From induced abortions to education on human relationships and sex). In: Raskauden keskeyttäminen - Suomalaisia valintoja 1990-luvulla, edited by M. Rimpelä and M. Ritamo, pp. 15-29. Raportteja, No. 126. Helsinki: Stakes, National Research and Development Centre for Welfare and Health.

Ramirez, F. and E. McEneaney. 1997. From women's suffrage to reproduction rights? Crossnational considerations. International Journal of Comparative Sociology 38 (1-2): 624.

Rasimus, A. 1993. Tilastoja raskauden keskeytyksistä (Statistics on induced abortions). In: Raskauden keskeytykset vuoteen 1991 Suomessa. Official Statistics of Finland. Health 1993:3. Helsinki: Stakes, National Research and Development Centre for Welfare and Health.

Rimpelä, M. 1993. Johdannoksi (Introduction). In: Raskauden keskeyttäminen - Súomalaisia valintoja 1990-luvulla, edited by M. Rimpelä and M. Ritamo. Raportteja, No. 126. Helsinki: Stakes, National Research and Development Centre for Welfare and Health.

Scott, J. 1998. Generational changes in attitudes to abortion: A cross-national comparison. European Sociological Review 14 (2): 177-190.

Scott, J. and H. Schuman. 1988. Attitude strenght and social action in the abortion dispute. American Sociological Review 53 (4):785-793. 
Söderling, I. 1997. Maahanmuuttoasenteet ja elämänhallinta (Attitudes toward immigration and life management). Väestötutkimuslaitoksen julkaisusarja D30/1997. Helsinki: Väestöntutkimuslaitos, Väestöliitto.

Tamney, J., S. Johnson, and R. Burton. 1992. The abortion controversy: Conflicting beliefs and values in American society. Journal for the Scientific Study of Religion 31 (1):3246.

Wilcox, C. 1989. Political action committees and abortion: A longitudinal analysis. Women and Politics 9 (1):1-19. 


\section{Appendices}

Table 1. Definitions and scoring of the variables used in the analysis.

\section{Variable}

Endogenous Variables

Stratification hierarchies

Income

Educational attainment

Occupation

Age

Exogenous Variables

Political orientation

\section{Religiosity}

1

2

Gender role attitudes

1

2

Opposition to abortion 1

2

\section{Definition (and Scoring)}

Factor loading $(\lambda)$

In thousands of Finnmarks per month

Years in education

ISCO; 6 dummies: 'Unskilled worker' (ref.), 'Skilled manual worker', 'Routine non-manual worker', 'White collar employee', 'Self-employed' 'and Other occupation'

In years $1^{(a)}$

$1^{(a)}$

$1^{(a)}$ each

"For which party did you vote for in the previous

$1^{(\mathrm{a})}$

Parliamentary election?'

"Which of the following options best describes your faith in

God?" Answering options: "I don't believe in God" (0.0), "I

am almost sure God does not exist" (25.0), "Sometimes I

believe in God, sometimes I don't" (50.0), "I am almost sure

God exists" (75.0), "I know God really exists and I have no

doubts about it" (100).

"Do you believe in Heaven?" Answering options: "No,

definitely not" $(0.0)$ to "Yes, definitely" (100.0).

"Familylife suffers when the woman has a full-time job"

Answering options: "Strongly disagree" $(0.0)$ to "Strongly agree" (100.0).

"A husband's job is to earn money; a wife's job is to look after the home and family" Answering options as above.

Do you think abortion is justifiable...

$\ldots$ if the mother so decides (Answering options as above)

... if the child would be disabled (Answering options as above)

... in a case where there is poverty or social problems (Answering options as above)

(a) Fixed loading (b) Leftist League (0.0), Social Democrats (12.5), The Green Party (25.0), No political affiliation (50.0), Swedish national Party, Center Party and Christian league (.75), Conservative Party (100.0). 
Table 2. Attitudes toward abortion in Finland. Distributions.

Item

Do you think abortion is justifiable...

.... in the case the mother so decides

$\ldots$ if the child would be disabled

$\ldots$ in a case of poverty or social problems
Agrees or strongly

agrees, \%
Neither agrees or disagrees, \%
Disagrees or strongly disagrees, $\%$

$\begin{array}{lll}59.9 & 16.2 & 23.9 \\ 74.7 & 15.0 & 10.4 \\ 57.4 & 16.6 & 25.0\end{array}$

Table 3. Predictors of opposition to abortion. Maximum likelihood parameters. (All parameters significant at the 5 percent level; $\mathrm{D}=$ direct effect; $\mathrm{I}=$ =indirect effect.)

\begin{tabular}{|c|c|c|c|c|c|c|c|}
\hline & \multirow{2}{*}{$\begin{array}{c}\text { Religiosity } \\
\text { D }\end{array}$} & \multicolumn{2}{|c|}{$\begin{array}{l}\text { Political } \\
\text { Orientation }\end{array}$} & \multicolumn{2}{|c|}{$\begin{array}{l}\text { Support for Traditional } \\
\text { Gender Roles }\end{array}$} & \multicolumn{2}{|c|}{$\begin{array}{l}\text { Opposition to } \\
\text { Abortion }\end{array}$} \\
\hline & & $\mathrm{D}$ & I & $\mathrm{D}$ & I & $\mathrm{D}$ & I \\
\hline \multicolumn{8}{|l|}{ Gender } \\
\hline Male & ref. & ref & ref. & ref. & ref. & ref. & ref. \\
\hline Female & .29 & -.11 & .06 & -.19 & .03 & -.18 & .08 \\
\hline Age & .08 & -.08 & .02 & .27 & - & - & .02 \\
\hline Education & - & .25 & - & -.22 & - & .12 & - \\
\hline \multicolumn{8}{|c|}{ 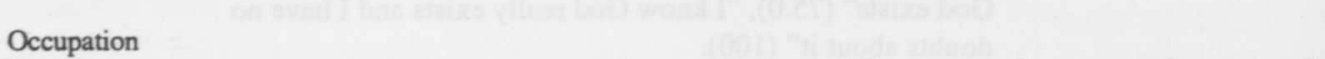 } \\
\hline Unskilled worker & ref. & ref. & ref. & ref. & ref. & ref. & ref. \\
\hline Skilled manual & - & -.09 & - & - & - & - & - \\
\hline Routine non-manual & - & - & - & - & - & - & - \\
\hline White collar & .08 & - & - & - & - & - & - \\
\hline Self-employed & - & - & - & - & - & - & - \\
\hline Other occupation & - & - & - & - & - & - & - \\
\hline Income & -.14 & - & -.03 & -.14 & -.02 & - & -.04 \\
\hline Religiosity & & .20 & - & .12 & - & .27 & - \\
\hline \multicolumn{2}{|l|}{ Political orientation } & & & $\cdot$ & $\cdot$ & $\cdot$ & - \\
\hline $\begin{array}{l}\text { Support for } \\
\text { traditional gender } \\
\text { roles }\end{array}$ & & & & $\sqrt{4}=a^{2}$ & & - & - \\
\hline $\mathrm{R}^{2}$ & .10 & .12 & & .24 & & .09 & \\
\hline$\chi^{2}$ & 91.50 (50 d.f.) & & & & & & \\
\hline GFI & .98 & & & & 2 & & \\
\hline RMSEA & .033 & & . & & & & \\
\hline
\end{tabular}

